\title{
Frequency and spatial distribution of animal and object hoarder behavior in Curitiba, Paraná State, Brazil
}

\section{Frequência e distribuição espacial do acúmulo compulsivo de animais e objetos em Curitiba, Paraná, Brasil}

\section{Frecuencia y distribución espacial del acúmulo compulsivo de animales y objetos en Curitiba, Paraná, Brasil}

Graziela Ribeiro da Cunha ${ }^{1}$

Camila Marinelli Martins 2

Marília de Fátima Ceccon-Valente 3

Liana Ludielli da Silva 3

Flavia Dias Martins ${ }^{3}$

Dirciane Floeter 4

Jyothi Vinnakota Robertson 5,6

Fernando Ferreira 2

Alexander Welker Biondo

\begin{abstract}
This study aimed to establish the frequency and spatial distribution of animal and object hoarding in Curitiba (Parana State), the eighth most populous city in Brazil. All hoarding complaints received by the City Secretaries of Health, Environment and Social Assistance between September 2013 and April 2015 were collected $(n=226)$ and suspicious cases were individually investigated. A total of 113/226 (50\%) of complaints were confirmed as hoarding cases, representing an overall ratio of 6.45 cases per 100,000 inhabitants in Curitiba, of which 48/113 (42.5\%) involved object hoarders, 41/113 (36.3\%) animal hoarders and 24/113 (21.2\%) both animal and object hoarders. A correlation of total identified cases with neighborhood population density and all population stratums analyzed (total, gender, age) was significantly positive $(p<0.01)$, and with neighborhood mean monthly income $(r=-0.2 ; p=0.03)$ significantly negative. A spatial cluster of cases was found in the north of the city $(O R=8.57 ; p<0.01)$. Hoarding cases were relatively frequent in Curitiba and were associated with population distribution patterns and inversely related to neighborhood income.
\end{abstract}

Hoarding Disorder; Obsessive Hoarding; Pets

\section{Correspondence}

\section{G. R. Cunha}

Departamento de Medicina Veterinária, Universidade Federal do Paraná.

Rua dos Funcionários 1540, Curitiba, PR 80035-050, Brasil. graziela.ribeiro@ufpr.br

1 Departamento de Medicina Veterinária, Universidade Federal do Paraná, Curitiba, Brasil.

2 Departamento de Medicina Veterinária Preventiva e Saúde Animal, Universidade de São Paulo, São Paulo, Brasil.

3 Secretaria Municipal da Saúde, Prefeitura Municipal de Curitiba, Curitiba, Brasil.

4 Secretaria Municipal do Meio Ambiente, Prefeitura Municipal de Curitiba, Curitiba, Brasil.

5 University of California, Davis, U.S.A.

6 JVR Shelter Strategies, Davis, U.S.A. 


\section{Introduction}

Mental disorders represent almost $12 \%$ of the global disease burden and account for substantial economic public health costs in a wide range of population groups, particularly those in social vulnerability 1 . Hoarding may be defined as a particular mental disorder characterized by a persistent difficulty with discarding or disposing of possessions, regardless of their value, with serious hindrance to living spaces and harmful consequences for the person, their family and community 2 . In addition, hoarding behavior (accumulation) has been reported to be a consequence of other mental disorders such as neurodevelopmental disorders, schizophrenia spectrum and other psychotic disorders, major depressive episodes, obsessive-compulsive disorder and neurocognitive disorders 2.

Hoarding behavior has reportedly impacted on public health due to extreme clutter leading to unsanitary living conditions, disease harboring and spreading (particularly zoonoses), risk of falls, fire hazard, obstruction of fire exits, endangering local public health, safety and welfare 3,4,5.

Hoarding behavior and its negative consequences have been considered a growing environmental concern for public health, related also to poor physical health, increased risk of injury, exacerbation of chronic diseases, occupational impairment, social concerns including risk of homelessness and social isolation, and economic burdens 6,7 . When associated with frustrations expressed by family members, hoarding behavior and its consequences may cause a strain on relationships 6 . Conditions of hoarding behavior may worsen when animal accumulation is involved 3 , singly or in association with object hoarding, exacerbating complaints by neighbors of animal noise and the smell of feces 3,4,8,9.

Animal hoarding has not only been defined as multiple pet ownership 10 or as just an animal welfare issue 11 , but also as a failure to provide minimal standards of animal care ${ }^{4}$. Animal hoarders may deny the consequences of such failures and display obsessive behaviors aimed at maintaining of increasing the animal population, even under deteriorating conditions, as a result of a lack of perception 4. In addition, failure to provide care may compromise animal welfare and lead to animal suffering, abuse, and cruelty 12 which may trigger criminal prosecution sooner than public health concerns and interventions.

Animal hoarding was first reported in the early 1980s, when 31 cases of multiple animal ownership in New York City (USA) were presented 10; and a further 54 cases from across the USA were reported in the late 1990s 4 . Cases have also been described outside the USA, with 6 cases in Canada 13, 24 in Spain 8, and 22 and 29 in two independent studies in Australia 9,14. Based on an intervention approach, animal hoarders have been classified in three general groups: overwhelmed caregiver, rescuer and exploiter 15 .

A review of studies published between 1981 and 2014 on hoarding cases, mainly focused on determining the prevalence of hoarding or number of cases, is provided in Table 1 . The majority of previous studies have been focused on the case description and demographic characteristics of the hoarders, mainly in developed countries and without any epidemiological data.

However, to the authors' knowledge, no hoarding study on epidemiological or distribution characteristics has been carried out to date in developing countries, including Brazil. Accordingly, the aim of this study was to establish the hoarding behavior frequency, spatial distribution and correlation with demographic characteristics in Curitiba, Paraná State, Brazil.

\section{Methods}

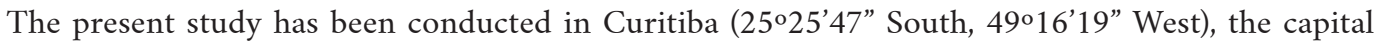
of Paraná State and the eighth most populous city in Brazil (Figure 1). Curitiba has a population of $1,751,907$ inhabitants distributed in 75 neighborhoods, with a mean of 23,359 (289 to 172,669) inhabitants per neighborhood and mean income of BRL 2,405.29 (854.89 to 6,184.93) (USD equivalent on 30 April 2015: mean 798.56, ranging from 283.82 to 2,053.42) per neighborhood, according to data from the latest population census conducted by the Brazilian Institute of Geography and Statistics (IBGE) 16. This study was developed with a cross sectional ecological design. 
Table 1

Review of published studies investigating mainly prevalence or number of hoarding cases from 1981 to 2014.

\begin{tabular}{|c|c|c|c|c|c|c|}
\hline \multicolumn{2}{|c|}{ Hoarder } & \multirow[t]{2}{*}{ Local } & \multirow[t]{2}{*}{ Period } & \multirow[t]{2}{*}{ Study method } & \multirow{2}{*}{$\begin{array}{c}\text { Case ratio or } \\
\text { prevalence (cases per } \\
\text { habitants) }\end{array}$} & \multirow[t]{2}{*}{ Reference } \\
\hline Objects & Animals & & & & & \\
\hline- & 31 & New York (USA) & 1973-1979 & $\begin{array}{c}\text { Direct interview of } 34 \text { suspicious } \\
\text { cases }\end{array}$ & $0.4 / 1,000,000$ overall & 10 \\
\hline- & 54 & 8 states (USA) & 1992-1996 & $\begin{array}{c}\text { Phone interview with } 25 \\
\text { organizations }\end{array}$ & $0.8 / 100,000 /$ year & 4 \\
\hline 36 & 17 & Massachusetts (USA) & $1992-1997$ & $\begin{array}{l}\text { Questionnaires to } 88 \text { health } \\
\text { officers }\end{array}$ & 26.3 complaints $/ 100,000$ & 3 \\
\hline 27 & - & Baltimore (USA) & 1997-1999 & $\begin{array}{l}\text { Direct interview, psychiatric exam } \\
\text { after random sampling }\end{array}$ & Prevalence 5.3\% & 29 \\
\hline- & 2 & Rio de Janeiro (Brazil) & $1998-2013$ & $\begin{array}{l}\text { Analysis of records of } 420 \\
\text { patients with OCD }\end{array}$ & $0.47 \%$ & 30 \\
\hline- & 22 & Victoria (Australia) & $2000-2014$ & $\begin{array}{l}\text { Phone/e-mail interview with } 31 \\
\text { councils }\end{array}$ & - & 14 \\
\hline \multirow[t]{2}{*}{ - } & 71 & $\begin{array}{c}28 \text { states (USA); } 1 \text { province } \\
\text { (Canada) }\end{array}$ & 2002 & $\begin{array}{c}\text { Interviews with } 71 \text { animal control, } \\
\text { police and health officers }\end{array}$ & - & 5 \\
\hline & 24 & Madrid (Spain) & $2002-2011$ & $\begin{array}{c}\text { Online interview with } 24 \\
\text { organizations }\end{array}$ & - & 8 \\
\hline- & 6 & Manitoba (Canada) & $2005-2007$ & $\begin{array}{c}\text { Interview with veterinarian after } \\
\text { case review }\end{array}$ & - & 13 \\
\hline 52 & 0 & London (UK) & $2005-2007$ & $\begin{array}{c}\text { Clinician-administered interview } \\
\text { and self-report }\end{array}$ & - & 21 \\
\hline - & 29 & New South Wales (Australia) & $2005-2011$ & $\begin{array}{c}\text { Retrospective analysis of database } \\
\text { records }\end{array}$ & $1-2 / 1,600,000 /$ year & 9 \\
\hline 105 & - & Germany & 2007 & Self-report & Prevalence $4.6 \%$ & 31 \\
\hline 19 & - & London (UK) & $2008-2011$ & $\begin{array}{l}\text { Direct interview, psychiatric exam } \\
\text { of } 99 \text { suspicious cases }\end{array}$ & Prevalence $1.5 \%$ & 19 \\
\hline 177 & - & Singapore & $2009-2010$ & $\begin{array}{l}\text { Face-to-face interviews with } \\
\text { residents }\end{array}$ & Prevalence $2.0 \%$ & 32 \\
\hline 295 & 53 & Madrid (Spain) & $2009-2012$ & $\begin{array}{c}\text { Records analyses of intervention } \\
\text { requests }\end{array}$ & - & 33 \\
\hline 25 & - & New York (USA) & 2010 & $\begin{array}{c}\text { Clinician-administered interview } \\
\text { and self-report }\end{array}$ & $\begin{array}{l}\text { Prevalence } 22.0 \% \\
\text { and } 23.0 \%\end{array}$ & 34 \\
\hline 78 & - & Italy & $2010-2011$ & Self-report & $\begin{array}{l}\text { Prevalence } 3.7 \% \\
\text { and } 6.0 \%\end{array}$ & 35 \\
\hline 191 & 129 & Florida (USA) & 2013 & $\begin{array}{l}\text { Questionnaires with code } \\
\text { enforcement officials and social } \\
\text { service workers }\end{array}$ & 33/100,000/year & 36 \\
\hline 72 & 65 & Curitiba (Brazil) & 2013-2015 & $\begin{array}{c}\text { Data analysis of complaints } \\
\text { and investigation of hoarder's } \\
\text { household }\end{array}$ & $6.45 / 100,000$ & $\begin{array}{c}\text { Present } \\
\text { study }\end{array}$ \\
\hline
\end{tabular}

OCD: obsessive-compulsive disorder.

The Curitiba City Hall has specific departments that are officially responsible for receiving complaints regarding problems with animals, health, the environment and social vulnerability, through a central telephone number. As a result, the city hall has a team of qualified inspectors who are exclusively responsible for investigating these complaints, and may include nurses, veterinarians, and/or biologists. The inspectors begin by means of direct observation of the environment and conditions of 
Figure 1

Map distribution of 113 identified hoarding cases in Curitiba, Paraná State, Brazil, from September 2013 to April 2015 showing urbanization and spatial cluster and mean monthly income per neighborhood.

1a) Urbanization and spatial cluster

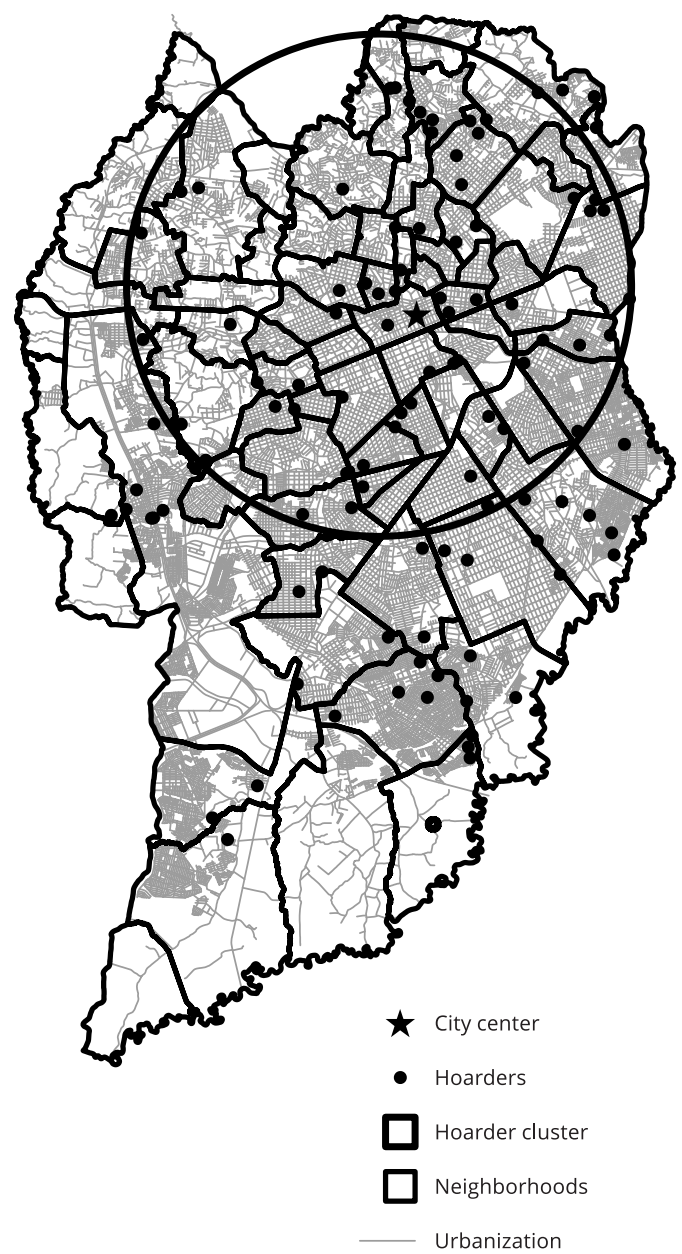

1b) Mean monthly income per neighborhood

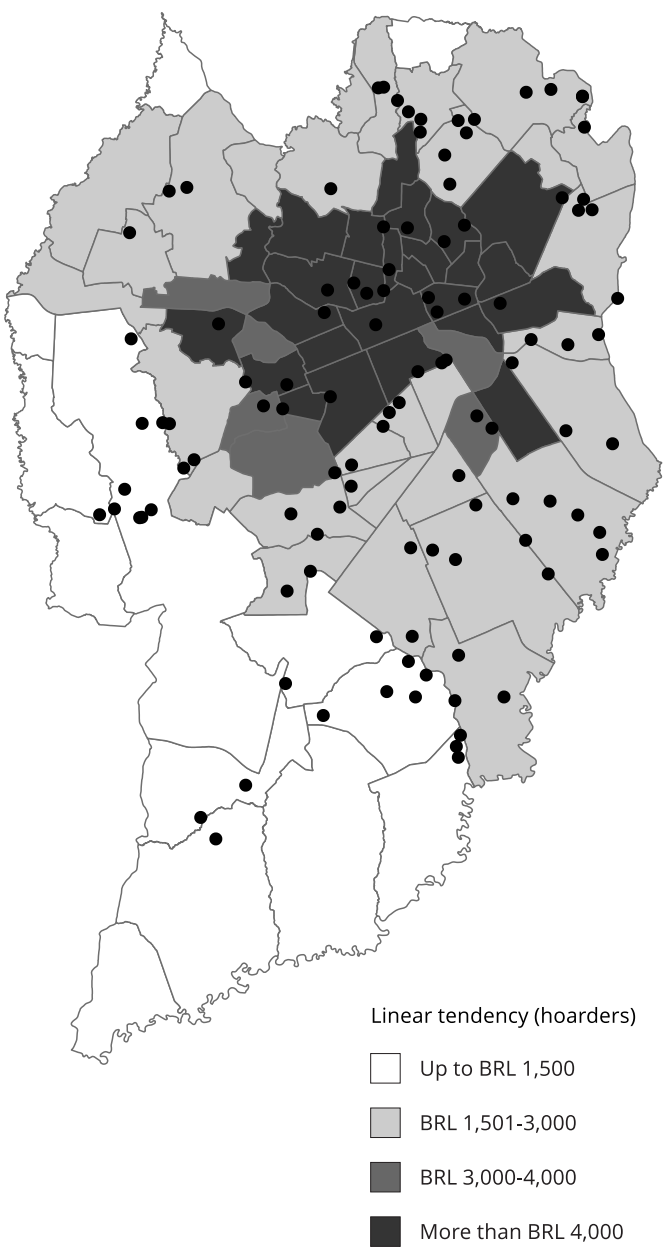

$\overbrace{S}^{N}$
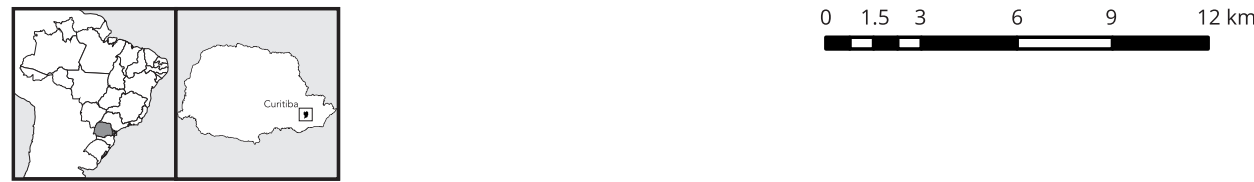

the animals during an investigation and may enter the house if necessary in order to better analyze the situation reported. At the same time, a hoarding workgroup has been formed with these public health professionals in partnership with psychologists, physicians of Curitiba City Hall and researchers at the Federal University of Paraná. This workgroup has carried out activities in consulting, discussion and training about hoarding, helping inspectors in identification and conducting cases. 
The basis used by inspectors to considerer a complaint to be a hoarding case was local observation of object and/or animal accumulation inside and/or outside the house at the time of the investigation and a historical preview of hoarding cases in the Curitiba government records. The criteria used specifically for the identification of object hoarding cases was local observation of a large amount of items accumulated without any apparent purpose that obstruct living spaces 2 and reports of difficulty in disposing of objects. The criteria used specifically for identifying animal hoarding cases was local observation of animal accumulation, lack of health standards, space, nutrition or veterinary care 15 and refusal to donate the animals. In summary, the case identification applied herein took into consideration the physical consequences of the hoarding behavior, which affected the family members and community, leading to the registration of complaints. All identified hoarding cases in this study were referred by the hoarding workgroup to psychiatrists and psychologists from the Curitiba City Hall to proceed with appropriate diagnosis and treatment where needed, though these were not included as part of this study.

The next step in the study involved the registration and analysis of all registered data regarding complaints and the results of investigations related to object and/or animal hoarding behavior received by the City Secretaries of Health, Environment and Social Assistance between September 2013 and April 2015. Despite the complexity of hoarding as an issue, the present study focused on epidemiological and general approaches. Therefore, hoarding cases were assessed using service forms rather than questionnaires and/or interviews with the hoarders and relatives, since no such study has been performed to date in Brazil.

The identified hoarding cases were analyzed on the basis of two ratios: (1) number of hoarding cases per 100,000 inhabitants and (2) number of inhabitants, number of women, number of men, number of elderly people (over the age of 60), number of elderly men and number of elderly women for each hoarding case. The frequencies of hoarding cases by neighborhood were correlated with the number of women, number of men, number of elderly people and mean monthly income per neighborhood. All demographic data drew on the most recent population census conducted by the IBGE 16. Correlations were evaluated using the Spearman test (significant p-value < 0.05) since the Kolmogorov-Smirnov test showed that the data did not follow a normal distribution frequency. Analyses were performed using a software that is available commercially (SPSS for Windows, version 16.0; SPSS Inc., Chicago, USA).

Corresponding geographic coordinates were obtained for each identified animal and/or object hoarding case and maps of the distribution and demographic characteristics of the hoarding cases were developed using a geographic information system (ArcGIS 10; http://www.esri.com/software/ arcgis/index.html). Subsequently, cluster analysis of hoarding numbers between neighborhoods were carried out by means of purely spatial scan analysis for clusters with high rates using the Discrete Poisson model 17 in SaTScan software (http: \\www.satscan.org).

The present study was approved by the Ethics Research Committee of the Health Sciences Sector at the Federal University of Paraná (protocol number 1,105,785/15) and by the Curitiba Secretaries of Health, the Environment and Social Assistance. Hoarding workgroup visits were officially included as part of the Curitiba hoarding policy program.

\section{Results}

A total of 226 hoarding complaints were obtained and investigated during the study period, of which 113 (50\%) were confirmed and 61 (27\%) discharged as hoarding cases, 32 (14.2\%) not present at the visit and $20(8.8 \%)$ with addresses not found. The confirmed hoarding cases represented a ratio of 6.45 hoarders per 100,000 inhabitants in Curitiba. The other calculated ratios showed that in Curitiba there was one hoarding case for every: 15,503 inhabitants; 7,390 men; 8,113 women; 1,753 elderly people (over the age of 60); 716 elderly men and 1,037 elderly women (Table 2).

Among the 113 identified cases, 48 (42.5\%) were classified as object hoarders, 41 (36.3\%) as animal hoarders and $24(21.2 \%)$ as both animal and object hoarding cases. Overall, animals were involved in $65(57.5 \%)$ and objects in $72(63.7 \%)$ hoarding cases (Figure 2), representing a ratio of 3.71 animal 


\section{Table 2}

Ratios of one hoarding case per numbers of inhabitants, women, men, elderly people, elderly men and women by neighborhood income. Curitiba, Paraná State, Brazil.

\begin{tabular}{|c|c|c|c|c|c|}
\hline Ratios & $\begin{array}{l}\text { Up to BRL 1,500 } \\
\text { (USD 498) }\end{array}$ & $\begin{array}{c}\text { BRL } 1,501 \text { to } 3,000 \\
\text { (USD } 498.33 \text { to } 996.01 \text { ) }\end{array}$ & $\begin{array}{c}\text { BRL } 3,001 \text { to } 4,000 \\
\text { (USD } 996.34 \text { to } 1,328.02 \text { ) }\end{array}$ & $\begin{array}{c}>\text { BRL 4,000 } \\
\text { (USD 1,328.02) }\end{array}$ & Total \\
\hline Hoarder : Inhabitant & $1: 19,386$ & $1: 12,539$ & $1: 17,964$ & $1: 17,548$ & $1: 15,504$ \\
\hline Hoarder : Men & $1: 9,423$ & $1: 5,972$ & $1: 8,260$ & $1: 7,944$ & $1: 7,390$ \\
\hline Hoarder : Women & $1: 9,969$ & $1: 6,564$ & $1: 9,705$ & $1: 9,604$ & $1: 8,113$ \\
\hline Hoarder : Elderly & $1: 1,530$ & $1: 1,503$ & $1: 3,110$ & $1: 3,105$ & $1: 1,753$ \\
\hline Hoarder : Elderly men & $1: 652$ & $1: 615$ & $1: 1,179$ & $1: 1,236$ & $1: 716$ \\
\hline Hoarder : Elderly women & $1: 878$ & $1: 888$ & $1: 1,931$ & $1: 1,869$ & $1: 1,037$ \\
\hline
\end{tabular}

Figure 2

Schematic diagram of investigated complaints and identified hoarding cases in Curitiba, Paraná State, Brazil, from September 2013 to April 2015.

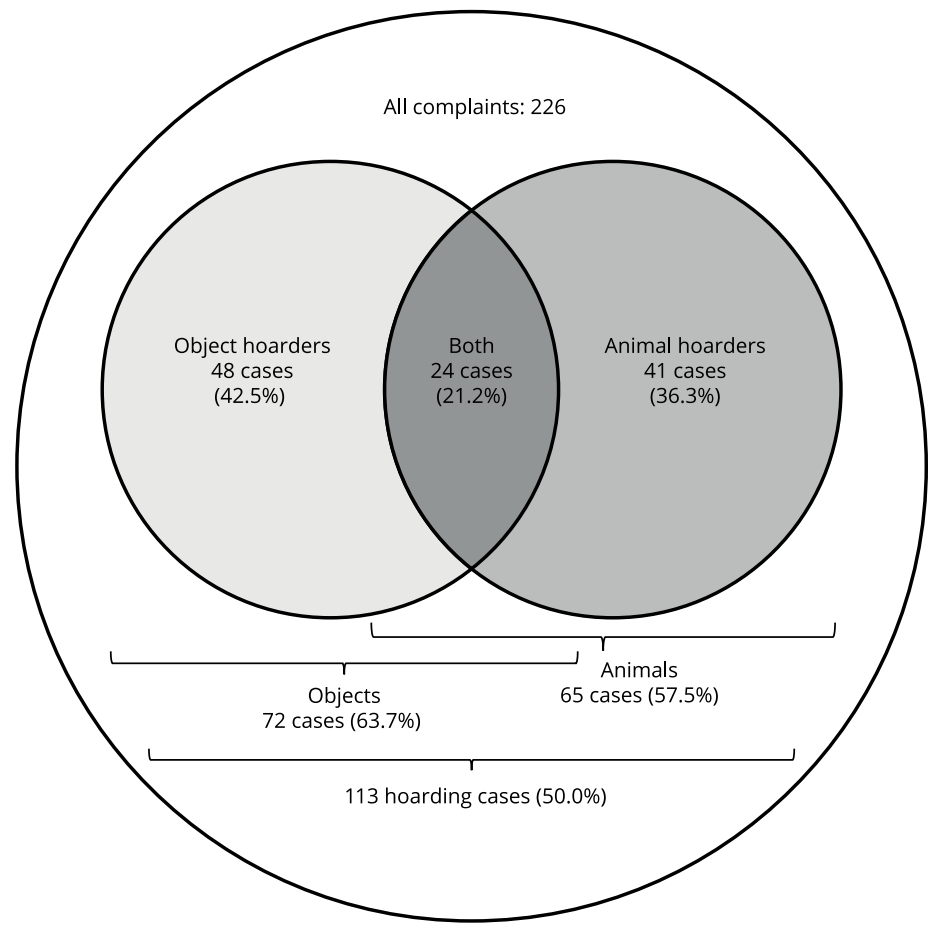

hoarding cases and 4.10 object hoarders per 100,000 inhabitants in Curitiba, or one animal hoarding for every 42,729 inhabitants and one object hoarder for every 36,498 .

The information about number of animals involved was available in 40/65 (61.5\%) animal hoarding cases, representing a total of 1,114 animals involved (mean of 27.8 animals per case), including 724 dogs (ranging from one to 105, with a mean of 19.5 per case) and 390 cats (ranging from one to 
60 , with a mean of 13.4 per case). The information about type of objects accumulated was available in 55/72 (76.38\%) object hoarding cases. One case may have more than one type of object accumulated. In 27/55 (49.09\%) of such cases, recyclable material had been accumulated, in 38/55 (69.09\%) rubbish, in 22/55 (40\%) garbage, in 19/55 (34.54\%) clothes and in 11/55 (20\%) other types of material.

The correlations of total identified cases with population density $(r=0.40)$, total population $(\mathrm{r}=0.68)$, male population $(\mathrm{r}=0.68)$, female population $(\mathrm{r}=0.68)$ and elderly population $(\mathrm{r}=0.65)$ were positive and significant $(\mathrm{p}<0.01)$. When analyses were developed proportionally, a significant and positive correlation was also found $(\mathrm{p}<0.01)$. This means that as the densities increased, the number of identified hoarders also increased. This was evident also in the linear tendency of accumulators following the variation of the population densities in the neighborhoods (Figure 3).

The correlation of identified hoarding cases with neighborhood mean monthly income was significant and negative $(\mathrm{r}=-0.24 ; \mathrm{p}=0.03)$. The mean monthly income was divided by strata and analyzed according to ratios of identified hoarders per demographic characteristics, showing that the strata between BRL 1,501 and BRL 3,000 (USD equivalent: 498.33-996.01) was with lower values of ratios (Table 2).

Regarding geographic distribution, the identified cases were distributed in 46/75 (61.3\%) neighborhoods ranging from one to nine, with a mean of 2.45 cases per neighborhood. A cluster of identified hoarding cases was found in the north of the city (Figure 1$)(\mathrm{OR}=8.57$; $<<0.01)$. When analyses of the distribution of animal and object hoarders were developed separately, no significant cluster was found.

\section{Figure 3}

Number of hoarders per neighborhood from September 2013 to April 2015 and demographic characteristics in Curitiba, Paraná State, Brazil.

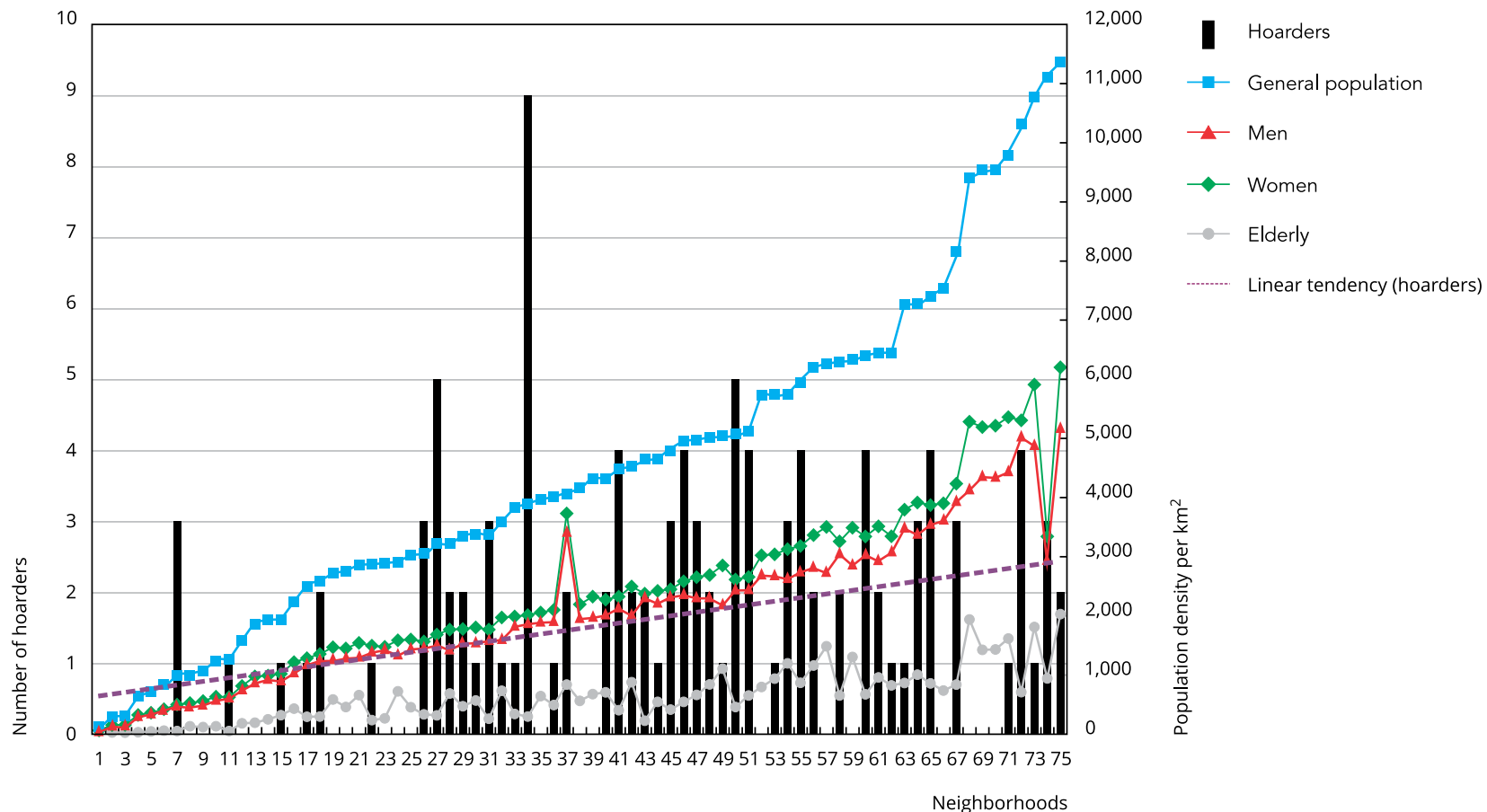




\section{Discussion}

Confirmed hoarding cases accounted for exactly half (50\%) of total complaints received in the present study period (Figure 2). This finding was higher, relatively, than previously found in Baltimore (USA) with only 27/735 (3.7\%) participants rated as "pathological" hoarding 18 and London (UK) with 19/99 (19.2\%) people meeting the criteria for hoarding disorder relating to accumulation and clutter 19 . Since the present study was based on complaints by three official city secretaries, results herein were probably more representative of the entire city than previous studies, which may have underestimated the local frequency of hoarders due to non-comprehensive survey methods.

Complaints ruled out as hoarding cases (27\%) were related to large amounts of recyclable material stored in organized, in-house conditions and mostly for resale; or multiple pets found in apparently adequate conditions 20 , involving either temporary or permanent housing, even in the case of foster homes. Although excluded as hoarding cases herein, workgroup visits were considered to be ruled out due to implications for public health and potential early stages of animal and/or object hoarding.

The ratio of 6.45 object and/or animal hoarders per 100,000 inhabitants found in the present study was lower the figure of 26.3, previously reported in Massachusetts (USA) 3; however, data over a five-year period was used in this study. The ratio of 3.71 animal hoarders per 100,000 inhabitants identified here was higher than the figures of 0.25 to 0.80 per 100,000 people previously reported in the USA 4 and 0.40 per 100,000 in New York City 10 . These contrasting results may be very important since this is the first report on the frequency of animal hoarding and ratios in Brazil, that may assist in the development of specific intervention strategies. Despite the fact that the authors have no apparent explanation for the higher proportion of animal hoarders compared to object hoarders, previous studies may not have found as many animal hoarders since surveys came mostly from only one source, limiting the sample. For example, a previous study reported no animal hoarding in a clinical sample of 52 hoarders with and without obsessive compulsive disorder 21. On the other hand, the data in our study were drawn from three main sources, involving complaints received by the Curitiba City Secretaries of Health, Environment and Social Assistance. Therefore, we hypothesize that our results may be more comprehensive and closer to reality in such populations. However, data may simply reflect more animal hoarders in Brazil than other places, since this is the first report on hoarding cases in Brazil.

Although the aim of the present study was not to take a comparative or clinical approach with regard to object hoarders versus animal hoarders, previous studies have shown that they differ in some respects. Animal hoarders appear to live in more squalid conditions, they tend to have only one species of animal, and cases are more prevalent among women, with higher rates of recidivism than object hoarders 22. However, both types of hoarders presented a chronic condition that involves intense emotional attachment to objects or animals and poor insight about the problem 22.

Based on the overall ratio, around 12,300 hoarding cases may be extrapolated to the entire 190 million inhabitants of Brazil 16 , or around 10,370 if only the $84.3 \%$ urban population is considered (since Curitiba is considered of $100 \%$ urban areas). No comparison is possible since, to the authors knowledge, this is the first report on overall hoarding cases in Brazil.

Among the confirmed animal hoarders in this study, 36.9\% were also object hoarders (Figure 2). Similar results were found previously in Spain and Australia, where $44 \%$ and $45.4 \%$ of animal hoarders presented signs of object hoarding, respectively 8,14. This finding has reinforced the critical role of veterinarians 13 and the need for cross-disciplinary approaches in cooperation between veterinarians and social service agencies, departments of health, fire, housing and mental health to better identify cases and to develop appropriate intervention strategies 5.

The mean number of animals involved per case for which such information was available was lower than the figures previously reported of 50 animals per case in Spain 8 and 34 cats or 23 dogs per owner in New York City 10. The involvement of dogs has been reported more frequently than cats, as has been found elsewhere in Spain 8 and Australia 9 but unlike results from North America 4,5,13. These differences may be attributed to a dog/cat ownership ratio of 7:1 in Brazil, particularly in Curitiba and the surrounding area 23,24 .

The present study has shown that the frequency of hoarding was consistent with neighborhood population increases in any tracts analyzed (Figure 3). What may therefore be inferred from this is 
that as neighborhood population increase, so the likelihood of a registered complaint rises, and thus more hoarding cases are identified. This finding reinforces the secretive nature of hoarders 4 , wherein accumulation may lead to the isolation of hoarders in their own homes rather than the choice of living in isolated areas, and this in turn may account for the high number of case absences reported at visits in this study. Moreover, the correlation of identified cases with neighborhood population density ( $\mathrm{p}<$ 0.01) may be considered intuitive since, excluding other associated factors, the more that people live within a specific area, the less available space they are likely to have, therefore making these spaces more easily obstructed.

The hoarding frequency reported here was inversely proportional to neighborhood income (Figures 1 and 3), showing that as neighborhood income decreases, the number of identified hoarders increases. This finding is consistent with mental disorders in general, which may affect those groups with the most adverse circumstances and the least resources 1 . On the other hand, previous studies have shown that approximately 80 to $90 \%$ of hoarding cases presented excessive acquisition problems, which may involve excessive buying, acquisition of free things or stealing 25,26,27. Although excessive buying may have a direct relationship with hoarder income, the means of acquiring objects and animals was not addressed in this study. In addition, the correlation coefficient reported here may be considered low $(r=-0.24 ; \mathrm{p}=0.03)$, suggesting that further studies should be performed to fully establish the relationship between hoarding frequency and income, particularly given the fact that the relationship with the hoarder's income, as opposed to neighborhood income, has been reported previously 18 . Regardless, the correlation reported here may reflect the reality of Brazil and both findings reinforce the potential for social exclusion of hoarders, as described previously 5,8,28.

An evident cluster of identified hoarding cases was found across a geographic distribution in the north of Curitiba (Figure 1) and may be due to more concentrated urbanization and population density in this region, since rapid urbanization has been associated with an increase in the burden of mental disorders 1. Complaints were more likely to occur (since the correlation between population density and total population to identified hoarding cases was statistically positive), but was different to a previous study in which the population was not correlated with the rate of hoarding complaints 3 .

The increase in complaints may also be due to other conditions related to hoarding behavior, such as clutter in the external area of the property, extreme unsanitary conditions, accumulation of junk, fire hazard, odor and odd behavior 3; it may also be related to the particular characteristics of the local community, which should be investigated further in Brazil.

Finally, although it was not the focus of the present study, the authors have found that abandoned puppies from neighborhood dogs and hoarder in-house litters may predispose or encourage animal hoarding (data not shown).

In conclusion, to the authors' knowledge, this study was the first assessment of hoarding cases in Brazil. This initial geographical and ecological approach performed herein provided a better analysis of data from the population level of a big city, and this may stimulate future interventions and the development of appropriate public health policies. Moreover, animal and/or object hoarding was found to be relatively frequent in southern Brazil, following population distribution patterns. It was also found to be inversely related to neighborhood income. Further studies with individual data should be performed and analyzed applying different epidemiological and statistical approaches. 


\section{Contributors}

G. R. Cunha contributed to the study conception and design, data acquisition, data analysis and interpretation, article drafting and final version for submission. C. M. Martins contributed to the study conception and design, statistical analysis, data interpretation, critical review of article and approval of final version. M. F. Ceccon-Valente, L. L. Silva, F. D. Martins and D. Floeter contributed to the study conception and design, critical review of article and approval of final version. J. V. Robertson contributed to the data analysis and interpretation, critical article review and approval of final version. F. Ferreira contributed to the statistical analysis, data interpretation, critical article review and approval of final version. A. W. Biondo contributed to the study conception and design, data interpretation, article drafting and final version for submission.

\section{References}

1. World Health Organization. Mental health policy and service guidance package: the mental health context. Geneva: World Health Organization; 2003.

2. American Psychiatric Association. Diagnostic and statistical manual of mental disorders (DSM-V). Arlington: American Psychiatry Publishing; 2013.

3. Frost RO, Steketee G, Williams L. Hoarding: a community health problem. Health Soc Care Community 2000; 8:229-34.

4. Patronek GJ. Hoarding of animals: an underrecognized public health problem in a difficultto-study population. Public Health Rep 1999; 114:81-7.

5. Hoarding of Animals Research Consortium. Health implications of animal hoarding. Health Soc Work 2002; 27:125-36.

6. Fleury G, Gaudette L, Moran P. Compulsive hoarding: overview and implications for community health nurses. J Community Health Nurs 2012; 29:154-62.

7. Tolin DF, Frost RO, Steketee G, Gray KD, Fitch KE. The economic and social burden of compulsive hoarding. Psychiatry Res 2008; 160:200-11.

8. Calvo P, Duarte C, Bowen J, Bulbena A, Fatjo J. Characteristics of 24 cases of animal hoarding in Spain. Anim Welf 2014; 23:199-208.

\section{Acknowledgments}

The authors are deeply thankful to professionals from the Curitiba Secretaries of Health, Environment and Social Assistance, and particularly to Debora Cancela, Jociene Pimentel, Emely G. P. Dias and Rita C. Garcia for their help in data collection and case discussion. This study was sponsored by the Araucária Foundation of Paraná (protocol number 41,769). Dr. G. R. Cunha was granted by the Brazilian National Research Council (CNPq).
9. Joffe M, O'Shannessy D, Dhand N, Westman M Fawcett A. Characteristics of persons convicted for offences relating to animal hoarding in New South Wales. Aust Vet J 2014; 92:369-75.

10. Worth D, Beck AM. Multiple ownership of animals in New York City. Trans Stud Coll Physicians Phila 1981; 3:280-300.

11. Honey L. Animal hoarding: not just an animal welfare issue. Vet Rec 2014; 174:569-71.

12. Patronek G. Animal hoarding: a third dimension of animal abuse. In: Ascione FR, editor. The international handbook of animal abuse and cruelty: theory, research, and application. West Lafayette: Purdue University Press; 2008. p. 221-40.

13. Reinisch AI. Characteristics of six recent animal hoarding cases in Manitoba. Can Vet J 2009; 50:1069-73.

14. Ockenden EM, De Groef B, Marston L. Animal hoarding in Victoria, Australia: an exploratory study. Anthrozoos 2014; 27:33-47.

15. Patronek GJ, Loar L, Nathanson JN. Animal hoarding: structuring interdisciplinary responses to help people, animals and communities at risk. North Grafton: Hoarding of Animals Research Consortium; 2006.

16. Instituto Brasileiro de Geografia e Estatística. Sinopse do Censo Demográfico 2010. http:// www.ibge.gov.br/home/ (accessed on 20/Dec/ 2015). 
17. Kulldorff M. A spatial scan statistic. Commun Stat Theory Methods 1997; 26:1481-96.

18. Samuels JF, Bienvenu OJ, Grados MA, Cullen B, Riddle MA, Liang K-Y, et al. Prevalence and correlates of hoarding behavior in a communitybased sample. Behav Res Ther 2008; 46:836-44.

19. Nordsletten AE, Reichenberg A, Hatch SL, Fernández De La Cruz L, Pertusa A, Hotopf M, et al. Epidemiology of hoarding disorder. Br J Psychiatry 2013; 203:445-52.

20. Ramos D, DaCruz NO, Ellis SLH, Hernandez JAE, Reche-Junior A. Early stage animal hoarders: are these owners of large numbers of adequately cared for cats? Hum Anim Interact Bull 2013; 1:55-69.

21. Pertusa A, Fullana MA, Singh S, Alonso P, Menchón JM, Mataix-Cols D. Compulsive hoarding: OCD symptom, distinct clinical syndrome, or both? Am J Psychiatry 2008; 165:1289-98.

22. Frost RO, Patronek G, Rosenfield E. Comparison of object and animal hoarding. Depress Anxiety 2011; 28:885-91.

23. Serafini CA, Rosa GA, Guimaraes AM, De Morais HA, Biondo AW. Survey of owned feline and canine populations in apartments from a neighbourhood in Curitiba, Brazil. Zoonoses Public Health 2008; 55:402-5.

24. Martins CM, Mohamed A, Guimarães AMS, de Barros CDC, Pampuch RDS, Svoboda W, et al. Impact of demographic characteristics in pet ownership: modeling animal count according to owners income and age. Prev Vet Med 2013; 109:213-8.

25. Grisham JR, Baldwin PA. Hoarding disorder cutting through the clutter. Med Today 2015; 16:26-33.

26. Frost RO, Steketee G, Tolin DF. Comorbidity in hoarding disorder. Depress Anxiety 2011; 28:876-84.

27. Frost RO, Rosenfield E, Steketee G, Tolin DF. An examination of excessive acquisition in hoarding disorder. J Obsessive Compuls Relat Disord 2013; 2:338-45.
28. Patronek GJ, Nathanson JN. A theoretical perspective to inform assessment and treatment strategies for animal hoarders. Clin Psychol Rev 2009; 29:274-81.

29. Samuels JF, Bienvenu OJ, Grados MA, Cullen B, Riddle MA, Liang K, et al. Prevalence and correlates of hoarding behavior in a communitybased sample. Behav Res Ther 2008; 46:836-44.

30. Campos-Lima AL, Torres AR, Yucel M, Harrison BJ, Moll J, Ferreira GM, et al. Hoarding pet animals in obsessive-compulsive disorder. Acta Neuropsychiatr 2015; 27:8-13.

31. Mueller A, Mitchell JE, Crosby RD, Glaesmer $\mathrm{H}$, de Zwaan M. The prevalence of compulsive hoarding and its association with compulsive buying in a German population-based sample. Behav Res Ther 2009; 47:705-9.

32. Subramaniam M, Abdin E, Vaingankar JA, Picco L, Chong SA. Hoarding in an Asian population: prevalence, correlates, disability and quality of life. Ann Acad Med Singapore 2014; 43:535-43.

33. Rodríguez Lozano E, Ortiz Fuillerat C, Blasco Novaldos G, Sáez Antón M, García Gutiérrez F, Bermejo Pérez C. Características sociodemográficas de las personas con conducta acumuladora/trastorno por acumulación (S. de Diógenes) en la ciudad de Madrid: serie de casos. Rev Asoc Esp Neuropsiquiatr 2014; 34:665-81.

34. Rodriguez CI, Herman D, Alcon J, Chen S, Tannen A, Essock S, et al. Prevalence of hoarding disorder in individuals at potential risk of eviction in New York City. J Nerv Ment Dis 2012; 200:91-4

35. Bulli F, Melli G, Carraresi C, Stopani E, Pertusa A, Frost RO. Hoarding behaviour in an Italian non-clinical sample. Behav Cogn Psychother 2014; 42:297-311.

36. McGuire JF, Kaercher L, Park JM, Storch EA. Hoarding in the community: a code enforcement and social service perspective. J Soc Serv Res 2013; 39:335-44. 


\section{Resumo}

O estudo teve como objetivo identificar a frequência e distribuição do acúmulo compulsivo de animais e objetos em Curitiba, Paraná, a oitava maior cidade do Brasil. Foram coletadas todas as denúncias de acúmulo compulsivo registradas pelas Secretarias Municipais de Saúde, Meio Ambiente e Assistência Social entre setembro de 2013 e abril de 2015, e casos suspeitos foram investigados individualmente. Do total de 226 denúncias, 113 (50\%) foram confirmadas como casos de acúmulo compulsivo, representando uma taxa geral de 6,45 casos por 100 mil habitantes em Curitiba, dos quais $48(42,5 \%)$ envolviam acumuladores de objetos, 41 (36,3\%) acumuladores de animais e 24 (21.2\%) acumuladores de animais e objetos. Foi identificada uma correlação positiva significativa $(p<0,01)$ entre os casos identificados e a densidade populacional do bairro e em todos os estratos populacionais analisados (total e por gênero e idade), e uma correlação negativa significativa ( $r=-0,2 ; p=0,03)$ com renda média do bairro. Foi encontrado um cluster espacial de cases na região norte da cidade $(O R=8,57 ; p<0,01)$. Os casos de acúmulo compulsivo mostraram-se relativamente frequentes em Curitiba e estiveram associados diretamente a padrões de distribuição populacional e inversamente à renda média do bairro.

Transtorno de Acumulação; Colecionismo Obsessivo; Animais de Estimação

\section{Resumen}

El estudio tuvo como objetivo identificar la frecuencia y distribución del acúmulo compulsivo de animales y objetos en Curitiba, Paraná, la octava mayor ciudad de Brasil. Se recogieron todas las denuncias de acúmulo compulsivo registradas por las Secretarías Municipales de Salud, Medio Ambiente y Asistencia Social, entre septiembre de $2013 y$ abril de 2015, y los casos sospechosos se investigaron individualmente. Del total de 226 denuncias, 113 (50\%) se confirmaron como casos de acúmulo compulsivo, representando una tasa general de 6, 45 casos por 100.000 habitantes en Curitiba, de los cuales $48(42,5 \%)$ involucraron a acumuladores de objetos, $41(36,3 \%)$ acumuladores de animales y 24 (21.2\%) acumuladores de animales y objetos. Se identificó una correlación positiva significativa $(p<0,01)$ entre los casos identificados y la densidad poblacional del barrio y en todos los estratos poblacionales analizados (total y por género $y$ edad); y una correlación negativa significativa ( $r$ $=-0,2 ; p=0,03)$ con renta media del barrio. Se encontró un clúster espacial de casos en la región norte de la ciudad $(O R=8,57 ; p<0,01)$. Los casos de acúmulo compulsivo se mostraron relativamente frecuentes en Curitiba y estuvieron asociados directamente a patrones de distribución poblacional e inversamente a la renta media del barrio.

Trastorno de Acumulación; Acaparamiento Obsesivo; Mascotas
Submitted on $05 / \mathrm{Jan} / 2016$

Final version resubmitted on 20/Apr/2016 Approved on 02/May/2016 